\title{
PENGARUH METODE PEMBELAJARAN DRILLS \\ TERHADAP HASIL BELAJAR DITINJAU DARI MOTIVASI BELAJAR SISWA DI SMKN 1 SEYEGAN
}

\author{
Muhammad Yusuf Darmawan \\ Program Pascasarjana Universitas Negeri Yogyakarta \\ uu_suf@yahoo.com
}

Abstrak

\begin{abstract}
Penelitian ini untuk mengetahui perbedaan hasil belajar KKPI antara siswa yang diajar dengan metode pembelajaran Computer Assisted Instruction (CAI) format drills dengan siswa yang diajar dengan metode pembelajaran demonstrasi ditinjau dari motivasi belajar siswa. Penelitian ini merupakan penelitian eksperimen semu. Sampel penelitian sebanyak 63 siswa, yang terdiri dari 31 siswa kelas eksperimen dengan diberikan perlakuan metode pembelajaran CAI format drills dan 32 siswa kelas kontrol dengan diberikan perlakuan metode pembelajaran demonstrasi. Teknik analisis data menggunakan analisis varians (ANAVA). Hasil penelitian 1) terdapat perbedaan hasil belajar KKPI antara siswa yang diajar dengan metode pembelajaran CAI format drills dengan siswa yang diajar dengan metode pembelajaran demonstrasi; (2) tidak terdapat interaksi antara metode pembelajaran CAI format drills dan metode pembelajaran demonstrasi dengan motivasi belajar terhadap hasil belajar KKPI siswa; (3) terdapat perbedaan hasil belajar KKPI antara siswa yang diajar dengan metode pembelajaran CAI format drills dengan siswa yang diajar dengan metode pembelajaran demonstrasi ditinjau dari siswa yang memiliki motivasi tinggi; 4) terdapat perbedaan hasil belajar KKPI antara siswa yang diajar dengan metode pembelajaran CAI format drills dengan siswa yang diajar dengan metode pembelajaran demonstrasi ditinjau dari siswa yang memiliki motivasi rendah.
\end{abstract}

Kata kunci: pengaruh, metode pembelajaran, drills, hasil belajar, motivasi belajar

\section{THE EFFECT OF DRILLS INSTRUCTIONAL METHOD ON LEARNING OUTCOME VIEWED FROM STUDENT LEARNING MOTIVATION IN SMKN 1 SEYEGAN}

\author{
Muhammad Yusuf Darmawan \\ Program Pascasarjana Universitas Negeri Yogyakarta \\ uu_suf@yahoo.com
}

\begin{abstract}
This research aims to find out the differences in learning KKPI outcomes between students who are taught using Computer-Assisted Instruction (CAI) format drills method and those taught using the demonstration method in terms of students' learning motivation. This research is a quasi experimental. The subjects were 63 students, consisting of 31 students in the experiment class using CAI format drills method and 32 students in the control class using demonstration method. Data analyze techniques used the analysis of variances (ANOVA). The result of this research: (1) There are differences in learning KKPI outcomes between the students who are taught using CAI format drills method and those taught using the demonstration method. (2) There is no interaction between CAI format drills method and demonstration method and the students' motivation on their learning KKPI outcomes. (3) There are differences in learning KKPI outcomes between the students who are taught using CAI format drills method and those taught using the demonstration method in terms of the high motivation of students. (4) There are differences in learning KKPI outcomes between students who are taught using CAI format drills method and those taught using the demonstration teaching method seen from the low motivation of the students.
\end{abstract}

Keyword: effects, learning method, drills, learning outcome, learning motivation 


\section{PENDAHULUAN}

Sekolah Menengah Kejuruan (SMK) merupakan bagian dari sistem pendidikan nasional. Ditegaskan dalam lampiran UndangUndang Sistem Pendidikan Nasional Nomor 22 Tahun 2006 tentang standar isi untuk satuan pendidikan dasar dan menengah yang menyatakan bahwa pendidikan kejuruan bertujuan untuk meningkatkan kecerdasan, pengetahuan, kepribadian, akhlak mulia, serta keterampilan peserta didik untuk hidup mandiri dan mengikuti pendidikan lebih lanjut sesuai dengan program kejuruannya. Agar dapat bekerja secara efektif dan efisien serta mengembangkan keahlian dan keterampilan, mereka harus memiliki stamina yang tinggi, menguasai bidang keahliannya dan dasardasar ilmu pengetahuan dan teknologi, memiliki etos kerja yang tinggi, dan mampu berkomunikasi sesuai dengan tuntutan pekerjaannya, serta memiliki kemampuan mengembangkan diri.

Perkembangan teknologi komputer saat ini begitu pesat, baik hardware maupun software. Semakin pesatnya perkembangan dalam bidang hardware maupun software komputer membuat aktivitas menjadi serba cepat serta menjadikan dunia seperti tanpa batas. Berbagai jenis informasi dapat diakses dengan cepat dan akurat. Salah satu contoh perkembangan software komputer yang dimaksud adalah software aplikasi microsoft office. Mata pelajaran KKPI (Keterampilan Komputer dan Pengelolaan Informasi) di SMK dimaksudkan untuk mempersiapkan peserta didik agar mampu mengantisipasi salah satu pesatnya perkembangan teknologi komputer tersebut.

Pada Sekolah Menengah Kejuruan (SMK), KKPI merupakan salah satu mata pelajaran kelompok adaptif yang perlu diperkenalkan, dipraktikkan, dan dikuasai oleh peserta didik sedini mungkin agar mereka memiliki bekal untuk menyesuaikan diri dalam kehidupan global serta dapat menggunakan teknologi komputer dan dapat mengaplikasikan program komputer sesuai dengan kompetensi kerja. Untuk menghadapinya diperlukan kemampuan dan kemauan belajar sepanjang hayat dengan cepat dan cerdas. Keberhasilan dalam mengembangkan keterampilan dan keahlian dalam bidang kejuruan khususnya mata pelajaran $\mathrm{Ke}$ - terampilan Komputer dan Pengelolaan Informasi (KKPI) dapat ditentukan oleh komponen pendidikan, salah satunya adalah kegiatan belajar mengajar. Di dalam sistem pendidikan, kegiatan belajar mengajar merupakan inti dari kegiatan pendidikan di sekolah dan kunci pokok dari terlahirnya hasil belajar.

Berdasarkan hasil observasi yang dilakukan di Sekolah Menengah Kejuruan Negeri 1 Seyegan pada mata pelajaran Keterampilan Komputer dan Pengelolaan Informasi diperoleh hasil bahwa hasil belajar KKPI semester genap tahun ajaran 2010/2011 masih tergolong rendah. Dari 11 kelas yang ada di kelas XI dengan jumlah siswa keseluruhan sebanyak 368 siswa, 315 siswanya $(85,59 \%)$ mendapat nilai di bawah nilai Kriteria Ketuntasan Minimal (KKM) sekolah yakni sebesar lebih dari atau sama dengan 75 . Dengan melihat besar persentase siswa yang mendapat nilai di bawah KKM sekolah, dapat disimpulkan bahwa pembelajaran KKPI belum sepenuhnya efektif dan tujuan pembelajaran belum sepenuhnya tercapai dengan baik dan optimal. Oleh karena itu hal yang perlu mendapat perhatian adalah proses kegiatan belajar mengajarnya baik dari segi guru maupun siswa agar hasil belajar teori siswa dalam mata pelajaran KKPI dapat meningkat. Memperbaiki proses belajar mengajar bukanlah sesuatu yang mudah, tapi perlu adanya upaya yang sistematis, terencana dan terprogram.

Perolehan hasil belajar KKPI yang masih dalam kategori rendah dipengaruhi oleh beberapa faktor, salah satunya adalah motivasi belajar. Motivasi dan belajar merupakan dua hal yang saling mempengaruhi. Motivasi belajar merupakan dorongan yang timbul dari dalam dan luar individu untuk melakukan perubahan tingkah laku. Motivasi belajar yang ada dalam diri siswa yang satu dengan yang lain berbeda-beda, ada siswa yang motivasi belajarnya tinggi dan ada juga yang motivasi belajarnya rendah.

Salah satu upaya untuk memperbaiki proses pembelajaran dari segi guru adalah dengan mengubah metode pembelajarannya, salah satu metode pembelajaran yang dimaksud adalah metode pembelajaran berbasis komputer atau biasa disebut dengan Computer Based Instruction (CBI). Heinich, R., Molenda, M., dan Russel, J.D (1989:356) menge- 
mukakan bahwa Computer Based Instruction (CBI) terdiri dari dua tipe, yaitu Computer Assisted Instruction (CAI) dan Computer Managed Instruction (CMI). Dengan demikian perlu dicari metode pembelajaran tipe Computer Based Instruction (CBI) yang tepat untuk pembelajaran KKPI, dalam hal ini peneliti ingin melihat pengaruh metode pembelajaran Computer Based Instruction (CBI) tipe Computer Assisted Instruction (CAI) format drills terhadap hasil belajar ditinjau dari motivasi belajar siswa pada pembelajaran KKPI bagi siswa kelas XI SMKN 1 Seyegan.

Pembelajaran Computer Assisted Instruction (CAI) format drills merupakan suatu metode pembelajaran dimana siswa melaksanakan kegiatan dengan mengerjakan soalsoal latihan yang disediakan oleh program komputer, sehingga diharapkan dengan mengerjakan latihan-latihan tersebut siswa dapat memperkuat penguasaan suatu konsep materi pembelajaran, memiliki kecepatan dalam mengerjakan soal-soal latihan, ketetapan, keterampilan serta kemampuan dalam menjalankan software komputer. Diharapkan jika metode pembelajaran Computer Assisted Instruction (CAI) format drills ini diterapkan hasil belajar teori siswa akan meningkat, oleh karena itu penelitian ini berupaya mengungkap hal tersebut.

Sesuai dengan latar belakang di atas, tujuan yang hendak dicapai dalam penelitian ini adalah untuk mengetahui 1) perbedaan hasil belajar KKPI antara siswa yang diajar dengan metode pembelajaran Computer Assisted Instruction (CAI) format drills dengan siswa yang diajar dengan metode pembelajaran demonstrasi; 2) pengaruh interaksi antara metode pembelajaran Computer Assisted Instruction (CAI) format drills dan metode pembelajaran demonstrasi dengan motivasi belajar terhadap hasil belajar KKPI siswa; 3 ) perbedaan hasil belajar KKPI antara siswa yang diajar dengan metode pembelajaran Computer Assisted Instruction (CAI) format drills dengan siswa yang diajar dengan metode pembelajaran demonstrasi ditinjau dari motivasi belajar.

\section{Hakikat Belajar}

Jensen, E dan Nickelsen, L (2008:8) mengemukakan bahwa belajar (learning) merupakan suatu proses untuk mendapatkan pengetahuan (knowledge), keterampilan (skills), sikap (attitude), konstruk mental, atau nilainilai melalui studi, pengalaman, atau pengajaran yang menyebabkan suatu perubahan yang dapat diukur. Sedangkan Smaldino, S.E., Lowther, D.L., dan Russell, J.D (2007:10) mengemukakan bahwa "learning is the development of new knowledge, skills, or attitudes as an individual interacts with information and the environment". Sementara itu Muhibbin Syah (2010:90) belajar merupakan tahapan perubahan seluruh tingkah laku individu yang relatif menetap sebagai hasil pengalaman dan interaksi dengan lingkungan yang melibatkan proses kognitif.

Dari berbagai definisi belajar tersebut di atas dapat dijelaskan bahwa belajar merupakan upaya seseorang dengan berbagai tahapan perubahan tingkah laku individu yang relatif menetap sebagai hasil pengalaman atau interaksi untuk memperoleh informasi dan mengembangkan pengetahuan, keterampilan, memperbaiki perilaku, sikap dan mengokohkan kepribadian melalui studi, pengalaman sehingga terbentuk tingkah laku baru.

\section{Hasil Belajar}

Agus Suprijono (2011:5) mengemukakan bahwa hasil belajar merupakan pola-pola perbuatan, nilai-nilai, pengertian-pengertian, sikap-sikap, apresiasi dan keterampilan. Sedangkan Dimyati dan Mudjiono (2009:250) mengemukakan bahwa hasil belajar merupakan hasil proses belajar atau proses pembelajaran. Sementara itu Nana Sudjana (2010:22) mengemukakan bahwa hasil belajar merupakan kemampuan-kemampuan yang dimiliki siswa setelah menerima pengalaman belajar. Di sisi lain menurut Purwanto (2010:54) hasil belajar merupakan perubahan perilaku yang terjadi setelah mengikuti proses belajar mengajar sesuai dengan tujuan pendidikan.

Dari paparan di atas dapat dijelaskan bahwa hasil belajar merupakan kemampuan yang dimiliki siswa yang berupa pola-pola perbuatan, nilai-nilai, pengertian-pengertian, sikap, apresiasi, keterampilan dan perubahan perilaku setelah mengalami proses belajar. Perubahan perilaku yang dimaksud tidak hanya perubahan pengetahuan, tetapi juga meliputi perubahan sikap dan keterampilan 


\section{Motivasi Belajar}

Sugihartono dkk (2007:20) mengemukakan bahwa motivasi merupakan suatu kondisi yang menyebabkan atau menimbulkan perilaku tertentu dan memberi arah serta ketahanan pada tingkah laku tersebut. Motivasi belajar yang tinggi tercermin dari ketekunan yang tidak mudah patah untuk mencapai sukses meskipun dihadang oleh berbagai kesulitan. Motivasi yang tinggi dapat menggiatkan aktivitas belajar siswa. Sedangkan Menurut Hamzah B. Uno (2011:8) mengemukakan bahwa motivasi merupakan dorongan dan kekuatan dalam diri seseorang untuk melakukan tujuan tertentu yang ingin dicapainya.

motivation is the psychological feature that arouses an organism to action toward a desired goal and elicits, controls, and sustains certain goal directed behaviors (http:// en.wikipedia.org/wiki/Motivation).

Motivasi merupakan fitur psikologis yang dapat membangkitkan suatu individu untuk bertingkah laku sesuai dengan tujuan yang diinginkan dan memunculkan, mengendalikan, memelihara serta mengarahkan tingkah laku tersebut sesuai dengan tujuan.

Sementara itu Dai, D.Y., dan Sternberg, R.J (2004:11) juga mengemukakan bahwa "broadly defined, motivation is indicated by the intensity (or energy), direction, and persistence of a goal-directed behavior or action". Motivasi didefinisikan secara luas, motivasi ditandai dengan intensitas (atau energi), arah, dan ketekunan dari perilaku yang diarahkan pada tujuan atau tindakan.

Dari peryataan di atas dapat dijelaskan bahwa motivasi belajar merupakan kondisi yang menimbulkan proses semangat dorongan belajar serta menimbulkan perubahan perilaku yang terarah dan mempunyai ketahanan pada perubahan perilaku tersebut. Belajar memerlukan energi dan harus terarah serta harus mempunyai tujuan yang jelas, oleh karena itu diperlukan motivasi belajar yang tinggi. Motivasi belajar yang tinggi akan menyebabkan siswa akan tidak mudah cepat patah semangat meskipun berbagai hambatan menghalanginya.

\section{Metode Pembelajaran}

Heinich, R., Molenda, M., dan Russel, J.D (1989:7) mengemukakan bahwa "methods are the procedures of instruction that are selected to help learners achieve the objectives or to internalize the content or message". Sedangkan menurut Ditjen PMPTK (2008:5) metode merupakan upaya untuk mengimplementasikan rencana yang sudah disusun dalam kegiatan nyata agar tujuan yang telah disusun tercapai secara optimal.

Dari uraian di atas dapat dijelaskan bahwa metode merupakan prosedur pembelajaran yang dipilih guru untuk membantu siswa dalam mencapai tujuan pembelajaran agar tercapai secara baik dan maksimal. Penggunaan sebuah metode pembelajaran merupakan hal yang sangat penting dan mutlak untuk dilakukan oleh seorang guru dalam rangka memberikan sebuah pemahaman materi pelajaran terhadap siswa.

Dalam penelitian ini metode pembelajaran yang dieksperimenkan guru KKPI meliputi (1) metode pembelajaran demonstrasi (2) metode pembelajaran Computer Assisted Instruction (CAI) format drills.

\section{Metode Demonstrasi}

Syaiful Bahri Djamarah dan Aswan Zain (2006:90) mengemukakan bahwa metode demonstrasi merupakan cara penyajian materi pembelajaran dengan cara memperagakan atau mempertunjukkan kepada siswa suatu proses, situasi, atau benda tertentu yang sedang dipelajari, baik sebenarnya ataupun tiruan, yang sering disertai dengan penjelasan lisan. Sedangkan menurut Sugihartono dkk (2007:83) metode demonstrasi merupakan metode pembelajaran dengan cara memperlihatkan suatu proses atau cara kerja suatu benda yang berkaitan dengan bahan pembelajaran. Sementara itu Smaldino, S.E., Lowther, D.L., dan Russel, J.D (2007:25) mengemukakan bahwa "in a demonstration, learners view a real or lifelike example of a skill or procedure to be learned".

Dari paparan di atas dapat dijelaskan bahwa metode demonstrasi merupakan metode yang digunakan guru dalam menyampaikan materi pembelajaran kepada siswa dengan cara memperagakan atau mempertunjukkan secara sistematis suatu proses dengan prosedur yang harus dipelajari secara benar yang 
disertai dengan penjelasan. Dalam pelaksanaan nyata metode demonstrasi, siswa dapat mengamati dan memperhatikan apa yang diperlihatkan dan diperagakan guru selama pembelajaran berlangsung. Dalam metode ini, kegiatan belajar mengajar berpusat pada guru atau guru banyak mendominasi kegiatan belajar mengajar karena dalam pelaksanaannya guru harus banyak memperagakan dan mempertunjukkan bahan pembelajaran yang diberikan kepada siswa. Sedangkan siswa hanya sekedar memperhatikan apa yang di demonstrasikan guru. Metode demonstrasi memerlukan kemampuan dan keterampilan guru yang khusus dan kemauan serta motivasi guru yang tinggi sehingga guru dituntut untuk lebih profesional serta demi keberhasilan proses pembelajaran siswa.

Sebagai suatu metode pembelajaran, Ditjen PMPTK (2008:16) mengemukakan bahwa metode demonstrasi memiliki beberapa kelebihan, antara lain:

1. Melalui metode demonstrasi, terjadinya verbalisme akan dapat dihindari, sebab siswa disuruh langsung memperhatikan bahan pelajaran yang dijelaskan;

2. Proses pembelajaran akan lebih menarik, sebab siswa tak hanya mendengar, tetapi juga melihat peristiwa yang terjadi; dan

3. Dengan cara mengamati secara langsung siswa akan memiliki kesempatan untuk membandingkan antara teori dan kenyataan. Dengan demikian siswa akan lebih meyakini kebenaran materi pembelajaran.

Disamping memiliki kelebihan, metode demonstrasi juga memiliki beberapa kekurangan, antara lain:

1. Metode demonstrasi memerlukan persiapan yang lebih matang, sebab tanpa persiapan yang memadai demonstrasi bisa gagal sehingga dapat menyebabkan metode ini tidak efektif lagi. Bahkan sering terjadi untuk menghasilkan pertunjukan suatu proses tertentu, guru harus beberapa kali mencobanya terlebih dahulu, sehingga dapat memakan waktu yang banyak;

2. Demonstrasi memerlukan peralatan, bahan-bahan, dan tempat yang memadai yang berarti penggunaan metode ini memerlukan pembiayaan yang lebih mahal dibandingkan dengan ceramah; dan
3. Demonstrasi memerlukan kemampuan dan keterampilan guru yang khusus, sehingga guru dituntut untuk bekerja lebih professional.

\section{Metode CAI Format Drills}

Heinich, R., Molenda, M., dan Russel, J.D (1989:357) mengemukakan bahwa "drills and practice program provide a variety of questions with varied formats". Sedangkan Alessi, S.M., dan Trollip, S.R (2001:11) mengemukakan bahwa "we use the term drill for practice which repeats the material to be learned until it is mastered". Sementara itu Azhar Arsyad (2009:160) mengemukakan bahwa drills merupakan latihan yang digunakan untuk mempermahir keterampilan atau memperkuat penguasaan konsep materi pembelajaran.

Dari paparan di atas dapat dijelaskan bahwa drills merupakan suatu program yang menyediakan bermacam-macam pertanyaan dengan format yang berbeda-beda yang digunakan untuk melatih secara berulang-ulang materi pelajaran sampai dapat mempermahir keterampilan serta menguasai materi yang telah dipelajari.

Dalam penerapan metode drills, Rusman (2011:285) mengemukakan bahwa ada empat tahapan yang harus dilakukan, tahapan tersebut yaitu:

1. Menyajikan masalah dalam bentuk latihan soal pada tingkat tertentu dari kemampuan dan performance siswa.

2. Siswa mengerjakan soal-soal latihan.

3. Program merekam penampilan siswa, mengevaluasi, kemudian memberikan umpan balik.

4. Jika jawaban yang diberikan siswa benar, program menyajikan materi selanjutnya dan jika jawaban siswa salah, program menyediakan fasilitas untuk mengulangi latihan (remedial) yang dapat diberikan secara parsial atau pada akhir keseluruhan soal.

Sebagai suatu metode pembelajaran, Smaldino, S.E., Lowther, D.L., dan Russell, J.D (2007:26-27) mengemukakan bahwa metode drills memiliki beberapa kelebihan, antara lain:

1. Umpan balik untuk memperbaiki (corrective feedback), para siswa mendapatkan umpan balik sebagai tindak perbaikan atas respons mereka; 
2. Memisah-misah informasi (information chunking), informasi disajikan dalam potongan kecil, yang memberikan kesempatan kepada siswa untuk menelaah kembali bahan-bahan pelajaran dalam potongan kecil; dan

3. Praktik yang telah terbentuk (built-in practice), praktik dibentuk menjadi potongan-potongan kecil informasi, yang memberikan kesempatan kepada siswa untuk langsung mencoba pengetahuan baru melalui cara-cara yang positif.

Disamping memiliki kelebihan, metode drills juga memiliki beberapa kekurangan, antara lain:

1. Repetitif (repetitive), tidak seluruh siswa me-respons dengan baik sifat repetitif dari latihan dan praktik;

2. Berpotensi membosankan (potentially boring), beberapa materi latihan dan praktik berisi terlalu banyak hal, yang artinya para siswa bisa menjadi bosan karena terlalu banyak pengulangan; dan

3. Praktik yang telah terbentuk (learning potential), jika seorang siswa melakukan kesalahan yang sama, menerapkan materi latihan dan praktik tidak membantu siswa dalam belajar.

Berdasarkan latar belakang masalah dan kajian teori di atas, dapat dirumuskan hipotesis penelitian sebagai berikut.

1. Terdapat perbedaan hasil belajar KKPI antara siswa yang diajar dengan metode pembelajaran Computer Assisted Instruction (CAI) format drills dengan siswa yang diajar dengan metode pembelajaran demonstrasi.

2. Terdapat pengaruh interaksi antara metode pembelajaran Computer Assisted Instruction (CAI) format drills dan metode pembelajaran demonstrasi dengan motivasi belajar terhadap hasil belajar KKPI siswa.

3. Terdapat perbedaan hasil belajar KKPI antara siswa yang diajar dengan metode pembelajaran Computer Assisted Instruction (CAI) format drills dengan siswa yang diajar dengan metode pembelajaran demonstrasi ditinjau dari siswa yang memiliki motivasi tinggi.

4. Terdapat perbedaan hasil belajar KKPI antara siswa yang diajar dengan metode pembelajaran Computer Assisted Instruction (CAI) format drills dengan siswa yang diajar dengan metode pembelajaran demonstrasi ditinjau dari siswa yang memiliki motivasi rendah.

\section{METODE}

Dalam penelitian ini akan diujikan sejauh mana pengaruh penggunaan metode pembelajaran Computer Assisted Instruction (CAI) format drills terhadap hasil belajar ditinjau dari motivasi belajar siswa.

Penelitian ini merupakan penelitian eksperimen semu (quasi-experimental research) dengan desain faktorial $2 \times 2$ yang dilakukan dengan memberikan perlakuan dalam bentuk metode pembelajaran. Penelitian dibagi menjadi dua kelas, kelas eksperimen dan kelas kontrol. Kelas eksperimen akan diberikan perlakuan metode pembelajaran Computer Assisted Instruction (CAI) format drills sedangkan pada kelas kontrol diberikan perlakuan dengan metode pembelajaran demonstrasi. Rancangan penelitian yang digunakan dalam penelitian ini adalah rancangan faktorial $2 \times 2$.

Penelitian ini dilakukan di Sekolah Menengah Kejuruan Negeri (SMKN) 1 Seyegan. Sedangkan waktu penelitian adalah Semester Genap Tahun Pelajaran 2011/2012. Populasi penelitian ini adalah siswa kelas XI dengan Kompetensi Keahlian Teknik Kendaraan Ringan. Melalui teknik purposive sampling diperoleh kelas XI TKR 1 dengan jumlah siswa 34 siswa dan XI TKR 3 dengan jumlah siswa 34 siswa.

Dalam penelitian ini terdapat 3 buah variabel, yaitu 1 variabel yaitu bebas yaitu metode pembelajaran yang dikelompokkan menjadi Computer Assited Instructions (CAI) format Drills dan metode pembelajaran demonstrasi, variabel terikat (hasil belajar), dan variabel moderator (motivasi belajar).

Berdasarkan analisis butir dan uji reliabilitas untuk instrumen angket motivasi belajar diperoleh 38 butir dinyatakan valid dengan $r$ hitung berkisar antara 0,367 sampai dengan 0,578 ( $\mathrm{r}$ tabel $=0,349$ ), dengan koefisien reliabilitas $(\alpha)$ sebesar 0,909. Sedangkan untuk instrumen soal hasil belajar, hasil analisis item dengan program Iteman diperoleh 28 butir soal yang dinyatakan valid dengan taraf kesukaran antara 0,361 sampai dengan 0,667 , sedang rentang daya beda antara 0,271 sampai dengan 0,632 , dengan 
koefisien reliabilitas tes hasil belajar sebesar 0,916 .

Data penelitian dianalisis dengan teknik analisis varians (ANAVA) dua jalan dengan taraf signifikansi yang digunakan sebesar 0,05 dan dilanjutkan uji Scheffe.

Tabel 1. Desain Penelitian Faktorial 2 x 2

\begin{tabular}{ccc}
\hline Metode Pembelajaran (A) & $\begin{array}{c}\text { Computer Assisted Instruction (CAI) } \\
\text { format drills } \\
\text { (A1) }\end{array}$ & $\begin{array}{c}\text { Demonstrasi } \\
\text { (A2) }\end{array}$ \\
\hline Motivasi Belajar (B) & A1 B1 & A2 B1 \\
Motivasi Tinggi (B1) & A1 B2 & A2 B2 \\
\hline
\end{tabular}

Keterangan:

A1B1: Kelompok siswa yang diajar dengan metode pembelajaran Computer Assisted Instruction (CAI) format drills ditinjau dari siswa yang memiliki motivasi tinggi

A1B2: Kelompok siswa yang diajar dengan metode pembelajaran Computer Assisted Instruction (CAI) format drills ditinjau dari siswa yang memiliki motivasi rendah

A2B1: Kelompok siswa yang diajar dengan metode pembelajaran demonstrasi ditinjau dari siswa yang memiliki motivasi tinggi
A2B2: Kelompok siswa yang diajar dengan metode pembelajaran demonstrasi ditinjau dari siswa yang memiliki motivasi rendah

\section{HASIL PENELITIAN DAN \\ PEMBAHASAN}

\section{Deskripsi Data}

Data hasil belajar KKPI seperti yang terlihat pada Tabel 2 berikut ini.

Tabel 2. Desain Penelitian Faktorial 2x2

\begin{tabular}{|c|c|c|c|c|}
\hline Sumb & atistik & $A_{1}$ & $\mathrm{~A}_{2}$ & $\sum \mathrm{b}$ \\
\hline \multirow{6}{*}{$\mathrm{B}_{1}$} & $\mathrm{n}$ & 13 & 13 & 26 \\
\hline & Min & 64,29 & 42,86 & 42,86 \\
\hline & $\operatorname{Max}$ & 85,71 & 75,00 & 85,71 \\
\hline & $\sum$ & 985,71 & 828,57 & 1814,28 \\
\hline & $\bar{X}$ & 75,82 & 63,73 & 69,78 \\
\hline & SD & 6,03 & 8,97 & 9,70 \\
\hline \multirow{6}{*}{$\mathrm{B}_{2}$} & $\mathrm{n}$ & 18 & 19 & 37 \\
\hline & Min & 57,14 & 53,57 & 53,57 \\
\hline & Max & 92,86 & 78,57 & 92,86 \\
\hline & $\Sigma$ & 1407,11 & 1282,15 & 2689,26 \\
\hline & $\bar{X}$ & 78,17 & 67,48 & 72,68 \\
\hline & SD & 8,65 & 7,13 & 9,49 \\
\hline \multirow{6}{*}{$\sum \mathrm{a}$} & $\mathrm{n}$ & 31 & 32 & \\
\hline & Min & 57,14 & 42,86 & \\
\hline & Max & 92,86 & 78,57 & \\
\hline & $\sum$ & 2392,82 & 2110,72 & \\
\hline & $\bar{X}$ & 77,18 & 65,96 & \\
\hline & SD & 7,64 & 8,01 & \\
\hline
\end{tabular}


Keterangan:

$\mathrm{A}_{1}$ : Kelompok siswa yang diajar dengan metode pembelajaran Computer Assisted Instruction (CAI) format drills

$\mathrm{A}_{2}$ : Kelompok siswa yang diajar dengan metode pembelajaran demonstrasi

$\mathrm{B}_{1}$ : Kelompok siswa yang memiliki motivasi tinggi

B2: Kelompok siswa yang memiliki motivasi rendah

n: Jumlah Data Observasi

$\overline{\mathrm{X}}$ : Skor rerata hasil belajar

SD: Simpangan baku/standar deviation

\section{Uji Persyaratan}

Uji normalitas data hasil belajar KKPI dilakukan terhadap enam kelompok sampel penelitian, dengan menggunakan formula Lilliefors pada taraf signifikansi $\alpha=0,05$ menunjukkan bahwa keenam kelompok sampel penelitian ini bersumber dari populasi data berdistribusi normal.

Pengujian homogenitas varians terhadap tiga kelompok sampel penelitian dengan menggunakan uji Bartlett. Hasil perhitungan homogenitas varians dua ke- lompok (A1 dengan A2) mempunyai varians yang sama (homogen), dengan harga $\mathrm{F}$ hitung $=1,10$ dan $F$ tabel $=1,84(0,05: 30: 30)$. Hasil perhitungan homogenitas varians dua kelompok (A1B1 dengan A2B1) mempunyai varians yang sama (homogen), dengan harga $\mathrm{F}$ hitung $=2,21$ dan $\mathrm{F}$ tabel $=2,69$ (0,05:12:12). Hasil perhitungan homogenitas varians dua kelompok (A1B2 dengan A2B2) mempunyai varians yang sama (homogen), dengan harga $\mathrm{F}$ hitung $=1,47$ dan $\mathrm{F}$ tabel $=$ $2,25(0,05: 16: 18)$.

\section{Pengujian Hipotesis}

Pengujian hipotesis dalam penelitian ini tentang perbedaan hasil belajar siswa dari tiga kelompok sampel penelitian, yaitu: (1) A1 dengan A2, (2) A1B1 dengan A2B1, dan (3) A1B2 dengan A2B2. Analisis data dalam penelitian ini menggunakan statistik parametrik dengan menggunakan analisis varians (ANAVA) dua jalan dan dilanjutkan dengan uji Scheffe. Rangkuman hasil analisis varians (ANAVA) dua jalan disajikan dalam Tabel 3 berikut ini.

Tabel 3. Rangkuman Hasil Analisis Varian (ANAVA) Dua Jalan Data Hasil Belajar KKPI

\begin{tabular}{|c|c|c|c|c|c|}
\hline Sumber Varian & $\begin{array}{l}\text { Jumlah } \\
\text { Kuadrat }\end{array}$ & $\mathrm{dk}$ & $\begin{array}{c}\text { Rerata } \\
\text { Kuadrat }\end{array}$ & $\mathrm{F}_{\text {Hitung }}$ & $\mathrm{F}_{\text {Tabel }(\alpha=0,05)}$ \\
\hline Metode Pembelajaran & 1980,198 & 1 & 1980,198 & 32,531 & 4,00 \\
\hline Kategori Motivasi & 141,742 & 1 & 141,742 & 2,329 & 4,00 \\
\hline $\begin{array}{l}\text { Metode Pembelajaran/ } \\
\text { Kategori Motivasi } \\
\text { (Interaksi) }\end{array}$ & 7,443 & 1 & 7,443 & 0,122 & 4,00 \\
\hline Dalam Kelompok & 3591,435 & 59 & 60,872 & - & - \\
\hline Jumlah & 327660,827 & 62 & - & - & - \\
\hline
\end{tabular}

Setelah dilakukan analisis data penelitian, maka dilakukan pembahasan sebagai berikut:

\section{Perbedaan Hasil Belajar KKPI Antara Siswa yang Diajar dengan Metode Pembelajaran Computer Assisted Instruction (CAI) Format Drills dengan Siswa yang Diajar dengan Metode Pembelajaran Demonstrasi}

Hipotesis yang diajukan dalam penelitian ini menyatakan bahwa terdapat perbedaan hasil belajar antara siswa yang diajar dengan metode pembelajaran Computer Assisted Instruction (CAI) format drills dengan siswa yang diajar dengan metode pembelajaran demonstrasi diterima. Rata-rata hasil belajar metode pembelajaran Computer Assisted Instruction (CAI) format drills lebih tinggi dibandingkan dengan rata-rata hasil belajar metode pembelajaran demonstrasi ( $\overline{\mathrm{X}}$ $=77,18>\bar{X}=65,96)$. Rata-rata hasil belajar metode pembelajaran Computer Assisted Instruction (CAI) format drills juga lebih 
tinggi jika dibandingkan dengan batas Kriteria Ketuntasan Minimal (KKM) SMKN 1 Seyegan $(\bar{X}=77,18>K K M=75)$. Hal ini menunjukkan bahwa metode pembelajaran Computer Assisted Instruction (CAI) format drills lebih unggul dibandingkan dengan metode pembelajaran demonstrasi.

Metode pembelajaran Computer Assisted Instruction (CAI) format drills menekankan perbedaan individual baik dalam kemampuan maupun dalam kecepatan. Pada metode pembelajaran ini, siswa difasilitasi oleh perangkat lunak yang berupa latihanlatihan soal serta siswa dapat berinteraksi secara langsung dengan media interaktif berbasis komputer sedangkan guru hanya sebagai programmer pembelajaran. Soal latihan yang telah dimasukkan ke dalam program komputer dikerjakan oleh siswa dengan waktu yang terbatas dan langsung diberikan umpan balik yang berupa tanggapan benar atau salah. Setelah siswa mengerjakan, maka akan diketahui berapa nilai yang telah dicapai oleh siswa tersebut. Jika siswa belum mencapai skor yang ditetapkan, maka tampilan di layar monitor komputer akan menunjukkan belum berhasil, sebaliknya jika skor siswa sudah mencapai skor yang ditetapkan, maka tampilan di layar monitor komputer akan menunjukkan sudah berhasil. Bagi siswa yang belum berhasil dapat mengerjakan soal latihan secara berulang-ulang sampai mencapai nilai yang ditetapkan. Dengan latihan berulang-ulang maka akan tertanam dan kemudian menjadi kebiasaan serta dapat menguji kemampuan siswa melalui kecepatan penyelesaian soalsoal latihan sampai mencapai ketuntasan dalam belajar.

Pada metode pembelajaran demonstrasi, guru menyajikan materi dari awal sampai akhir dengan cara memperagakan kepada siswa tentang suatu proses. Di sini peran guru sangat dominan dan kegiatan belajar mengajar hanya berpusat pada guru serta kurang memperhatikan keaktifan siswa, sehingga siswa akan cepat bosan. Peran siswa hanya sekedar memperhatikan apa yang didemonstrasikan oleh guru. Pada metode pembelajaran ini diperlukan kemampuan dan keterampilan guru yang khusus, guru dituntut untuk bisa dan menguasai materi pembelajaran yang akan didemonstrasikan, jika tidak maka pembelajaran demonstrasi akan gagal dan tidak efektif.
Interaksi Antara Metode Pembelajaran Computer Assisted Instruction (CAI) format drills dan metode pembelajaran demonstrasi dengan motivasi belajar terhadap hasil belajar KKPI siswa

Dalam penelitian ini tidak menemukan adanya interaksi antara metode pembelajaran Computer Assisted Instruction (CAI) format drills dan metode pembelajaran demonstrasi dengan motivasi belajar dalam pengaruhnya terhadap hasil belajar siswa. Rata-rata hasil belajar siswa yang diajar dengan metode pembelajaran Computer Assisted Instruction (CAI) format drills lebih tinggi dibanding rata-rata hasil belajar siswa yang diajar dengan metode pembelajaran demonstrasi.

Ditinjau dari siswa yang memiliki motivasi tinggi maupun rendah, rata-rata hasil belajar siswa yang diajar dengan metode pembelajaran Computer Assisted Instruction (CAI) format drills lebih tinggi dibandingkan dengan rata-rata hasil belajar siswa yang diajar dengan metode pembelajaran demonstrasi. Hal ini menunjukkan bahwa metode pembelajaran Computer Assisted Instruction (CAI) format drills lebih unggul dibandingkan dengan metode pembelajaran demonstrasi.

Pada metode pembelajaran Computer Assisted Instruction (CAI) format drills, ratarata hasil belajar siswa yang memiliki motivasi tinggi lebih rendah dibandingkan dengan rata-rata hasil belajar siswa memiliki motivasi rendah. Siswa yang memiliki motivasi tinggi akan cepat bosan pada tugastugas yang sifatnya rutin dan berulang-ulang, sehingga merasa kurang kreatif. Metode pembelajaran Computer Assisted Instruction (CAI) format drills memberi kesempatan pada siswa untuk berinteraksi secara langsung dengan media interaktif berbasis komputer. Siswa mengerjakan soal-soal latihan yang telah dimasukkan ke dalam program komputer secara berulang-ulang dengan batas waktu tertentu sampai siswa dapat menguasai materi yang telah dipelajari. Oleh karena itu siswa yang memiliki motivasi tinggi akan cepat bosan jika diberikan metode pembelajaran Computer Assisted Instruction (CAI) format drills. Sebaliknya siswa yang memiliki motivasi rendah senang akan tugas-tugas yang sifatnya rutin dan berulang-ulang, meskipun kurang kreatif. Metode pembelajaran Computer Assisted Instruction (CAI) format drills 
cocok dan tepat jika diberikan pada siswa

yang memiliki motivasi rendah.

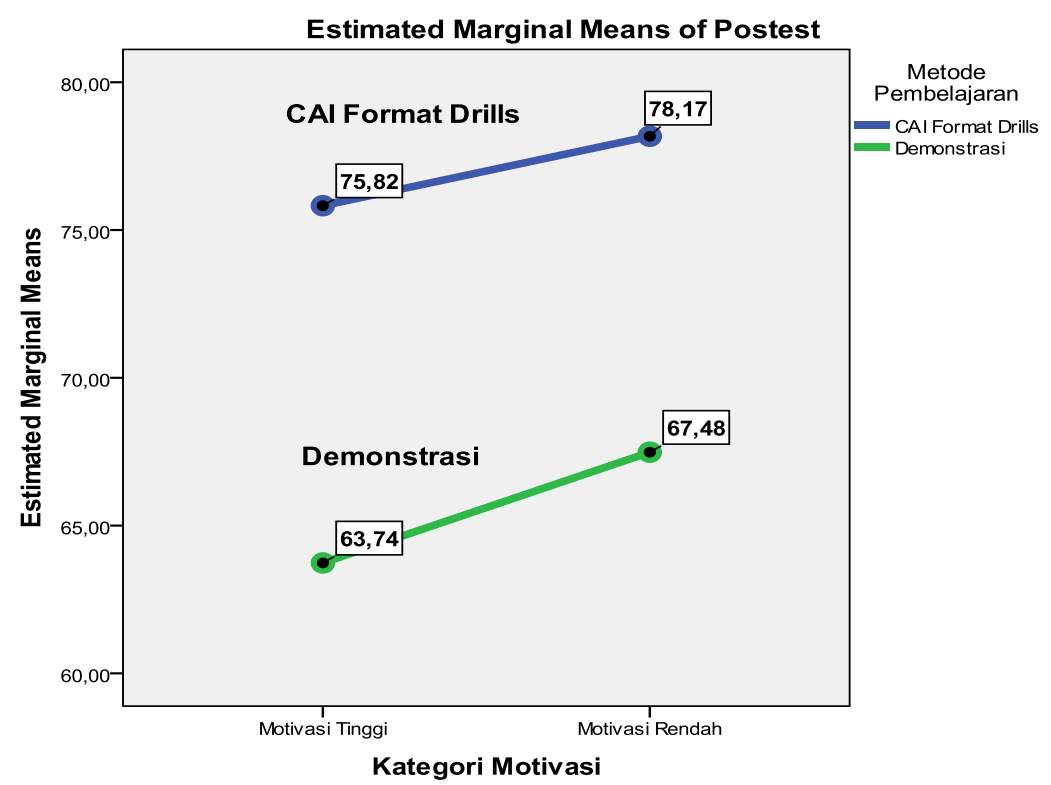

Gambar 1. Interaksi antara Metode Pembelajaran Computer Assisted Instruction (CAI)

Format Drills dan Metode Pembelajaran Demonstrasi dengan Motivasi Belajar Terhadap Hasil Belajar KKPI Siswa

Dari analisis varians (ANAVA) dua jalan terlihat bahwa terdapat perbedaan hasil belajar antara siswa yang diajar dengan metode pembelajaran Computer Assisted Instruction (CAI) format drills dengan siswa yang diajar dengan metode pembelajaran demonstrasi. Hasil analisis varians (ANAVA) tersebut kemudian dilanjutkan dengan uji Scheffe.

Tabel 4. Rangkuman Hasil Analisis Varians (ANAVA) Tahap Lanjut dengan Uji Scheffe

\begin{tabular}{lccc}
\hline \multicolumn{1}{c}{ Kelompok yang diperbandingkan } & $P_{\text {Value }}$ & Kondisi & Keterangan \\
\hline $\begin{array}{l}\text { Computer Assisted Instruction (CAI) format drills } \\
\text { dengan demonstrasi ditinjau dari siswa yang }\end{array}$ & 0,003 & $<0,05$ & Signifikan \\
memiliki motivasi tinggi & & & \\
$\begin{array}{l}\text { Computer Assisted Instruction (CAI) format drills } \\
\text { dengan demonstrasi ditinjau dari siswa yang } \\
\text { memiliki motivasi rendah }\end{array}$ & 0,002 & $<0,05$ & Signifikan \\
\hline
\end{tabular}

Perbedaan hasil belajar KKPI antara siswa yang diajar dengan metode pembelajaran Computer Assisted Instruction (CAI) format drills dengan siswa yang diajar dengan metode pembelajaran demonstrasi ditinjau dari siswa yang memiliki motivasi tinggi

Hipotesis yang diajukan dalam penelitian ini menyatakan bahwa terdapat perbedaan hasil belajar antara siswa yang diajar dengan metode pembelajaran Computer Assisted Instruction (CAI) format drills dengan siswa yang diajar dengan metode pembelajaran demonstrasi ditinjau dari siswa yang memiliki motivasi tinggi diterima. Ratarata hasil belajar metode pembelajaran Computer Assisted Instruction (CAI) format drills lebih tinggi dibandingkan dengan ratarata hasil belajar metode pembelajaran demonstrasi ditinjau dari siswa yang memiliki motivasi tinggi $(\overline{\mathrm{X}}=75,82>\overline{\mathrm{X}}$ $=63,73)$. Rata-rata hasil belajar metode pembelajaran Computer Assisted Instruction (CAI) format drills ditinjau dari siswa yang memiliki motivasi tinggi juga lebih tinggi 
jika dibandingkan dengan batas Kriteria Ketuntasan Minimal (KKM) SMKN 1 Seyegan $(\bar{X}=75,82>K K M=75)$. Hal ini menunjukkan bahwa metode pembelajaran Computer Assisted Instruction (CAI) format drills lebih unggul dibandingkan dengan metode pembelajaran demonstrasi ditinjau dari siswa yang memiliki motivasi tinggi.

Siswa yang memiliki motivasi tinggi tidak menyukai hal-hal yang bersifat rutinitas, ditambah lagi dalam metode Computer Assisted Instruction (CAI) format drills sangat berpotensi timbulnya keadaan dimana siswa akan cepat merasa bosan karena sangat dimungkinkan banyak terjadi pengulangan. Hal ini tentunya sangat tidak cocok dengan karakter siswa yang memiliki motivasi tinggi yang cenderung kreatif dan ingin mengembangkan pola pikirnya. Meskipun demikian, siswa yang memiliki motivasi tinggi ini termotivasi dengan adanya penilaian langsung (umpan balik) yang ada pada metode pembelajaran Computer Assisted Instruction (CAI) format drills, dan kondisi ini tidak terjadi pada metode pembelajaran demonstrasi yang selalu mengedepankan peran guru daripada siswa. Disamping itu, latihan-latihan yang ada pada program Computer Assisted Instruction (CAI) format drills disajikan dalam bentuk informasi-informasi kecil yang tentunya hal ini akan lebih mudah dipahami oleh siswa yang memiliki motivasi tinggi.

Perbedaan hasil belajar KKPI antara siswa yang diajar dengan metode pembelajaran Computer Assisted Instruction (CAI) format drills dengan siswa yang diajar dengan metode pembelajaran demonstrasi ditinjau dari siswa yang memiliki motivasi rendah

Hipotesis yang diajukan dalam penelitian ini menyatakan bahwa terdapat perbedaan hasil belajar antara siswa yang diajar dengan metode pembelajaran Computer Assisted Instruction (CAI) format drills dengan siswa yang diajar dengan metode pembelajaran demonstrasi ditinjau dari siswa yang memiliki motivasi rendah diterima. Rata-rata hasil belajar metode pembelajaran Computer Assisted Instruction (CAI) format drills lebih tinggi dibandingkan dengan hasil belajar metode pembelajaran demonstrasi ditinjau dari siswa yang memiliki motivasi rendah $(\bar{X}=78,17>\bar{X}=67,48)$. Rata-rata hasil belajar metode pembelajaran Computer Assisted Instruction (CAI) format drills ditinjau dari siswa yang memiliki motivasi rendah juga lebih tinggi jika dibandingkan dengan batas Kriteria Ketuntasan Minimal (KKM) SMKN 1 Seyegan $(\bar{X}=78,17>$ KKM =75). Hal ini menunjukkan bahwa metode pembelajaran Computer Assisted Instruction (CAI) format drills lebih unggul dibandingkan dengan metode pembelajaran demonstrasi ditinjau dari siswa yang memiliki motivasi rendah.

Berkebalikan dengan siswa yang memiliki motivasi tinggi, siswa yang memiliki motivasi rendah menyukai hal-hal yang bersifat rutinitas. Dalam metode pembelajaran Computer Assisted Instruction (CAI) format drills maupun metode pembelajaran demonstrasi, meskipun siswa sama-sama memiliki motivasi rendah, namun siswa yang memiliki motivasi rendah yang diajar dengan metode pembelajaran Computer Assisted Instruction (CAI) format drills lebih termotivasi dengan adanya umpan balik yang berupa penilaian langsung yang ada pada program Computer Assisted Instruction (CAI) format drills dari pada siswa yang diajar dengan metode pembelajaran demonstrasi yang selalu mengedepankan peran guru daripada siswa, ditambah lagi umpan balik yang berupa penilaian langsung dalam metode pembelajaran demonstrasi ini tidak ada. Dalam metode pembelajaran demonstrasi ini peran guru lebih dominan, sehingga hal ini menyebabkan siswa cepat bosan apalagi siswa yang diajar dengan metode pembelajaran demonstrasi ini memiliki motivasi rendah.

\section{SIMPULAN DAN SARAN}

\section{Simpulan}

1. Terdapat perbedaan hasil belajar KKPI antara siswa yang diajar dengan metode pembelajaran Computer Assisted Instruction (CAI) format drills dan siswa yang diajar dengan metode pembelajaran demonstrasi.

2. Tidak terdapat pengaruh interaksi antara metode pembelajaran Computer Assisted Instruction (CAI) format drills dan 
metode pembelajaran demonstrasi dengan motivasi belajar terhadap hasil belajar KKPI siswa.

3. Terdapat perbedaan hasil belajar KKPI antara siswa yang diajar dengan metode pembelajaran Computer Assisted Instruction (CAI) format drills dengan siswa yang diajar dengan metode pembelajaran demonstrasi ditinjau dari siswa yang memiliki motivasi tinggi.

4. Terdapat perbedaan hasil belajar KKPI antara siswa yang diajar dengan metode pembelajaran Computer Assisted Instruction (CAI) format drills dengan siswa yang diajar dengan metode pembelajaran demonstrasi ditinjau dari siswa yang memiliki motivasi rendah.

\section{Saran}

Metode pembelajaran Computer Assisted Instruction (CAI) format drills pada hakikatnya sebuah metode pembelajaran yang menggunakan software dan hardware komputer, oleh karena itu pembelajaran ini menuntut ketersediaan sarana dan prasarana yang memadai yang sepadan antara software dan hardware komputer. Sarana dan prasarana lain adalah ketersediaannya sumber listrik yang memadai. Metode pembelajaran Computer Assisted Instruction (CAI) format drills dilakukan secara serentak di laboratorium komputer dan menggunakan perangkat komputer dalam jumlah yang tidak sedikit, sehingga membutuhkan supply tegangan listrik yang memadai. Oleh karena pembelajaran ini selalu menggunakan komputer, maka komputer yang digunakan harus dalam keadaan baik dan normal, untuk itu komputer harus selalu dalam keadaan baik, baik dari segi hardware maupun software. Hal ini akan berimplikasi pada mahalnya biaya perawatan, oleh karena itu sekolah hendaknya dapat mengakomodasi permasalahan tersebut serta mengupayakan semaksimal mungkin untuk menyediakan fasilitas yang memadai demi terlaksananya pembelajaran ini.

\section{DAFTAR PUSTAKA}

Agus Suprijono. (2010). Cooperative Learning. Cetakan ke-5, Yogyakarta: Pustaka Pelajar
Dai, D.Y., \& Sternberg, R. J. (2004). Motivation, Emotion, and Cognition: Integrative Perspectives On Intellectual Development and Functioning. New Jersey: Lawrence Erlbaum Associates, Inc., Publishers

Dimyati dan Mudjiono. (2009). Belajar dan Pembelajaran. Jakarta: Rineka Cipta

Ditjen PMPTK. (2008). Strategi Pembelajaran dan Pemilihannya. Jakarta: Depdiknas

Hamzah. B. Uno. (2011). Teori Motivasi dan Pengukurannya. Jakarta: Bumi Aksara

Heinich, R., Molenda, M., \& Russel, J.,D. (1989). Instructional And New Technologies of Instruction. New York: Macmillan, Inc

Jensen, E \& Nickelsen, L. (2008). Deeper LEARNING 7 Strategi Luar Biasa untuk Pembelajaran yang Mendalam dan Tak Terlupakan. (Terjemahan Benyamin Molan). A SAGE Company Thousand Oaks: Corwin Press. (Buku asli diterbitkan tahun 2008)

Muhibbin Syah. (2011). Psikologi Belajar. Jakarta: Rajawali Pers

Motivation. Diambil pada tanggal 2 Juli 2012, dari http://en.wikipedia.org/wiki/ Motivation

Nana Sudjana. (2010). Penilaian Hasil Proses Belajar Mengajar. Bandung: PT. Remaja Rosdakarya.

Purwanto. (2010). Evaluasi Hasil Belajar. Yogyakarta: Pustaka Pelajar

Rusman. (2011). Manajemen Kurikulum, Edisi 1. Jakarta: Rajawali Pers

Sugihartono, dkk. (2007). Psikologi Pendidikan. Yogyakarta: UNY Press

Smaldino, S.E., Lowther, D.L. \& Russell, J.D. (2007). Instructional Technology and Media for Learning $\left(9 t^{h} e d\right)$. Colombus: Merrill

Syaiful Bahri Djamarah dan Azwan Zain. (2006). Strategi Belajar Mengajar. Jakarta: Rineka Cipta. 